\title{
Structure, magnetic and thermodynamic properties of heterometallic ludwigites: $\mathrm{Cu}_{2} \mathrm{GaBO}_{5}$ and $\mathrm{Cu}_{2} \mathrm{AlBO}_{5}$
}

\author{
R. M. Eremina ${ }^{a, *}$, T. P. Gavrilova ${ }^{a}$, E. M. Moshkina ${ }^{\mathrm{b}}$, I. F. Gilmutdinov ${ }^{\mathrm{c}}$, \\ R. G. Batulin' ${ }^{c}$, V. V. Gurzhiy ${ }^{d}$, V. Grinenko, ${ }^{e, f}$ D. S. Inosov ${ }^{f}$ \\ ${ }^{a}$ Zavoisky Physical-Technical Institute, FRC Kazan Scientific Center of RAS, Sibirsky tract, 10/7, \\ Kazan, 420029, Russia \\ ${ }^{b}$ Kirensky Institute of Physics, Federal Research Center KSC SB RAS, 660036 Krasnoyarsk, Russia \\ ${ }^{c}$ Institute of Physics, Kazan Federal University, 420008, Kazan, Russia \\ ${ }^{d}$ Department of Crystallography, Institute of Earth Sciences, St. Petersburg State University, \\ University Emb. 7/9, 199034, St. Petersburg, Russia \\ ${ }^{e}$ Leibniz Institute for Solid State and Materials Research, IFW Dresden, 01069, Dresden, \\ Germany \\ ${ }^{f}$ Institute for Solid State and Materials Physics, TU Dresden, 01069, Dresden, Germany
}

\begin{abstract}
We present an extensive study of the structural, magnetic and thermodynamic properties of high-quality monocrystals of the two heterometallic oxyborates from the ludwigite family: $\mathrm{Cu}_{2} \mathrm{GaBO}_{5}$ and $\mathrm{Cu}_{2} \mathrm{AlBO}_{5}$ in the temperature range above $2 \mathrm{~K}$. The distinctive feature of the investigated structures is the selective distribution of $\mathrm{Cu}$ and $\mathrm{Ga} / \mathrm{Al}$ cations. The unit cell of $\mathrm{Cu}_{2} \mathrm{GaBO}_{5}$ and $\mathrm{Cu}_{2} \mathrm{AlBO}_{5}$ contains four nonequivalent crystallographic sites of metal ions. Two sites in the structure from four nonequivalent crystallographic sites of metal ions of $\mathrm{Cu}_{2} \mathrm{GaBO}_{5}$ are fully occupied by $\mathrm{Cu}$ atoms which form the quasi one-dimensional chains along the $a$-axis. For $\mathrm{Cu}_{2} \mathrm{AlBO}_{5}$ all sites are partially occupied by $\mathrm{Al}$ and $\mathrm{Cu}$ atoms. The joint analysis of low-temperature data on magnetic susceptibility and magnetic contribution to the specific heat showed that $\mathrm{Cu}_{2} \mathrm{AlBO}_{5}$ and $\mathrm{Cu}_{2} \mathrm{GaBO}_{5}$ exhibit an antiferromagnetic transition at $T_{\mathrm{N}} \approx 3$ and $4 \mathrm{~K}$, respectively. The magnetic contributions to the specific heat for both compounds were obtained after subtracting the phonon contribution. It is shown that the external magnetic field above 2.5 T leads to a broadening of the magnetic phase transition indicating suppression of the long-range antiferromagnetic order.
\end{abstract}

Keywords: crystal structure, ludwigite, quasi-one-dimensional magnetism, antiferromagnetic order, specific heat, magnetization.

PACS: 75.30.Kz, 75.60.Ej, 75.70.Cn, 76.30.-v.

*REremina@yandex.ru 


\section{Introduction}

$\mathrm{Cu}_{2} \mathrm{GaBO}_{5}$ and $\mathrm{Cu}_{2} \mathrm{AlBO}_{5}$ oxyborates belong to the ludwigite family with the general formula $M_{2}^{2+} M^{\prime 3+} \mathrm{BO}_{5}$, where $M$ and $M^{\prime}$ are divalent and trivalent metal ions, respectively. During the last twenty years a lot of works were devoted to the investigations of bimagnetic ludwigites $\mathrm{Cu}_{2} \mathrm{MnBO}_{5}[1,12,3]$, $\mathrm{Mn}_{3-x} \mathrm{Ni}_{x} \mathrm{BO}_{5}$ [4], $\mathrm{Cu}_{2} \mathrm{FeBO}_{5}\left[\right.$ [5, 6], $\mathrm{Ni}_{2} \mathrm{FeBO}_{5}$ [7, 8], $\mathrm{Co}_{2} \mathrm{FeBO}_{5}[8]$ and others. Usually the investigations of ludwigites start from the detailed sample characterization, because the final sample composition can differ from the composition of the corresponding mixture of the starting components. In addition to the structural data, the magnetization $[2,3,4,5,7,8]$, specific heat [2, 8], neutron powder diffraction [2], Mössbauer spectroscopy [5, 7] measurements, and the calculations of the exchange integrals in frameworks of the indirect coupling model [1, 6] are presented in the literature.

Magnetic properties of oxyborates with the ludwigite structure are usually related with the presence of zigzag walls in their crystal structure formed by metal ions of different valency and also the presence of up to twelve magnetic ions in the unit cell, which occupy four nonequivalent positions. Usually the copper-containing ludwigites are characterized by the antiferromagnetic or ferrimagnetic ordering with low value of the uncompensated magnetic moment and low temperature of magnetic ordering.

Partial substitution of copper ions with $\mathrm{Co}^{2+}$ cations and occupation of trivalent positions with $\mathrm{Al}^{3+}$ cations leads to a significant anisotropy of the magnetic properties in $\mathrm{CuCoAlBO}_{5}$ [10]. Authors suggested that such a difference is due to the influence of the strong spin-orbit coupling of $\mathrm{Co}^{2+}$ ions, which leads to the canting of the magnetic moments on neighboring sublattices and causes a weak spontaneous magnetic moment [10]. Unlike other Cu-containing oxyborates, $\mathrm{Co}_{2.88} \mathrm{Cu}_{0.12} \mathrm{BO}_{5}$ is the highly anisotropic hard ferrimagnet with a large uncompensated moment [11]. However, the comparison of magnetic properties of $\mathrm{Co}_{2.88} \mathrm{Cu}_{0.12} \mathrm{BO}_{5}$ ludwigite with homometallic $\mathrm{Co}_{3} \mathrm{BO}_{5}$ showed that the replacement of cobalt ions with copper does not affect the magnetic properties of the sample: a slight decrease in the macroscopic magnetic moment and invariability of the ferrimagnetic ordering temperature $\left(T_{\mathrm{N}}=43 \mathrm{~K}\right)$ were observed [11]. The $\mathrm{Cu}_{3-x} \mathrm{Mn}_{x} \mathrm{BO}_{5}(x=2)$ ludwigite is characterized by the ferrimagnetic ordering below $T_{\mathrm{N}}=92 \mathrm{~K}$ demonstrating a possible increase in the macroscopic magnetic moment and the magnetic ordering temperature in ludwigites [12]. A completely different picture of phase transitions is observed in $\mathrm{Cu}_{2} \mathrm{FeBO}_{5}$ ludwigite, where the phase transition of the iron subsystem from the paramagnetic to the spin glass state was observed at $T=63 \mathrm{~K}$, the $\mathrm{Cu}^{2+}$ subsystem passes into a magnetically ordered state at $T_{\mathrm{N} 1}=38 \mathrm{~K}$, and only below $T_{\mathrm{N} 1}=20 \mathrm{~K}$ the sample is fully ordered [9].

Magnetic measurements and the analysis of exchange interactions in $\mathrm{Cu}_{2} \mathrm{FeBO}_{5}$ and $\mathrm{Cu}_{2} \mathrm{GaBO}_{5}$ showed that these compounds are antiferromagnetic (AFM) with Néel temperatures of 32 and $3 \mathrm{~K}$, respectively [5, 9]. The authors con- 
cluded that the magnetic properties of this type of compounds are substantially dependent on the degree of cation distribution over crystallographic positions. As follows from Ref. [9], $\mathrm{Cu}_{2} \mathrm{GaBO}_{5}$ is a low-dimensional magnetic system, for which magnetic transition to an attiferromagnetically ordered state was observed in the temperature dependence of magnetic susceptibility. A definitive answer can only be given by studing the temperature dependence of magnetic susceptibility on alternating current (AC) [13], which has not yet been carried out for the $\mathrm{Cu}_{2} \mathrm{GaBO}_{5}$ single crystal. The details of the synthesis process of $\mathrm{Cu}_{2} \mathrm{AlBO}_{5}$ ludwigite were previously reported [14], but the magnetic properties of this compound have not been investigated until now. The temperature dependencies of the specific heat were not obtained for $\mathrm{Cu}_{2} \mathrm{AlBO}_{5}$ and $\mathrm{Cu}_{2} \mathrm{GaBO}_{5}$.

Here we present the detailed investigations of structural, magnetic and thermodynamic properties of $\mathrm{Cu}_{2} \mathrm{GaBO}_{5}$ and $\mathrm{Cu}_{2} \mathrm{AlBO}_{5}$ ludwigites, which contain only one type of magnetic ion $\mathrm{Cu}^{2+}$. We suggest that these investigations will help in understanding the type of the magnetic ordering in the homomagnetic heterometallic ludwigites.

\section{Experimental methods and results}

\subsection{Chemical composition}

Small fragments of $\mathrm{Cu}_{2} \mathrm{GaBO}_{5}$ (1) and $\mathrm{Cu}_{2} \mathrm{AlBO}_{5}$ (2) were crushed, pelletized, and carbon coated. The chemical compositions of the samples were determined using a Hitachi TM 3000 scanning electron microscope equipped with an EDX spectrometer. Analytical calculations 1: Atomic ratio from structural data $\mathrm{Cu}$ 1.96, Ga 1.04; found by EDX: Cu 1.95, Ga 1.05. Analytical calculations 2: Atomic ratio from structural data $\mathrm{Cu}$ 1.82, $\mathrm{Al} 1.18$; found by EDX: $\mathrm{Cu}$ 1.84, Al 1.16.

In spite of the real atomic ratio $\mathrm{Cu}: \mathrm{Ga}$ (or $\mathrm{Cu}: \mathrm{Al}$ ) is not $2: 1$ in the investigated samples, in this work we use the ideal formula $\mathrm{Cu}_{2} \mathrm{GaBO}_{5}$ and $\mathrm{Cu}_{2} \mathrm{AlBO}_{5}$ instead $\mathrm{Cu}_{2.05} \mathrm{Ga}_{0.95} \mathrm{BO}_{5}$ and $\mathrm{Cu}_{1.81} \mathrm{Al}_{1.19} \mathrm{BO}_{5}$.

\subsection{Single-crystal X-ray diffraction study}

Crystal structures of $\mathbf{1}$ and $\mathbf{2}$ were determined by the means of singlecrystal X-ray diffraction analysis. Crystals were selected under an optical microscope, encased in oil-based cryoprotectant, and fixed on micro mounts. Diffraction data for $\mathbf{1}$ were collected at $293 \mathrm{~K}$ using a Bruker SMART diffractometer equipped with an APEX II CCD area detector operated with monochromated Mo $K_{\alpha}$ radiation $\left(\lambda\left[\operatorname{Mo} K_{\alpha}\right]=0.71073 \AA\right)$ at $40 \mathrm{kV}$ and $30 \mathrm{~mA}$. Data were collected with frame widths of $1.0^{\circ}$ in $\omega$ and $\varphi$, and an exposure of $2 \mathrm{~s}$ per frame. Data were integrated and corrected for background, Lorentz, and polarization effects by means of the Bruker programs APEX2 and XPREP. Absorption correction was applied using the empirical spherical model within the $S A D A B S$ 
Table 1: Crystallographic data for $\mathrm{Cu}_{2} \mathrm{GaBO}_{5}$ (1) and $\mathrm{Cu}_{2} \mathrm{AlBO}_{5}$ (2).

\begin{tabular}{|c|c|c|}
\hline Compound & $\overline{1}$ & $\overline{\overline{2}}$ \\
\hline $\begin{array}{c}\text { Formula } \\
\text { Crystal system }\end{array}$ & $\begin{array}{c}\mathrm{Cu}_{2.05} \mathrm{Ga}_{0.95} \mathrm{BO}_{5} \\
\text { monoclinic }\end{array}$ & $\begin{array}{c}\mathrm{Cu}_{1.81} \mathrm{Al}_{1.19} \mathrm{BO}_{5} \\
\text { monoclinic }\end{array}$ \\
\hline$a(\AA)$ & $3.1121(1)$ & $3.0624(2)$ \\
\hline$b(\AA)$ & $11.9238(3)$ & $11.7855(6)$ \\
\hline$c(\AA)$ & $9.4708(2)$ & $9.3747(6)$ \\
\hline$\alpha\left(^{\circ}\right)$ & 90 & 90 \\
\hline$\beta\left(^{\circ}\right)$ & $97.865(1)$ & $97.737(5)$ \\
\hline$\gamma\left({ }^{\circ}\right)$ & 90 & 90 \\
\hline$V\left(\AA^{2}\right)$ & $348.137(16)$ & $335.27(4)$ \\
\hline Molecular weight & 287.87 & 238.11 \\
\hline Space group & $P 2_{1} / c$ & $P 2_{1} / c$ \\
\hline$\mu\left(\mathrm{mm}^{-1}\right)$ & 19.595 & 11.742 \\
\hline Temperature (K) & 293(2) & 293(2) \\
\hline$Z$ & 4 & 4 \\
\hline$D_{\text {calc }}\left(\mathrm{g} / \mathrm{cm}^{3}\right)$ & 5.481 & 4.717 \\
\hline Crystal size $\left(\mathrm{mm}^{3}\right)$ & $0.18 \times 0.14 \times 0.09$ & $0.22 \times 0.16 \times 0.10$ \\
\hline Diffractometer & $\begin{array}{l}\text { Bruker Smart } \\
\text { Apex II }\end{array}$ & $\begin{array}{l}\text { Rigaku Oxford } \\
\text { Diffraction } \\
\text { Xcalibur Eos }\end{array}$ \\
\hline Radiation & $\operatorname{Mo} K_{\alpha}$ & $\operatorname{Mo} K_{\alpha}$ \\
\hline Total reflections & 9729 & 1711 \\
\hline Unique reflections & 1873 & 761 \\
\hline Angle range $2 \Theta\left(^{\circ}\right)$ & $5.53-79.20$ & $5.58-55.00$ \\
\hline $\begin{array}{l}\text { Reflections with } \\
\qquad\left|F_{\mathrm{o}}\right| \geq 4 F\end{array}$ & 1755 & 694 \\
\hline$R_{\text {int }}$ & 0.0394 & 0.0437 \\
\hline$R_{\sigma}$ & 0.0264 & 0.048 \\
\hline$R_{1}\left(\left|F_{\mathrm{o}}\right| \geq 4 F\right)$ & 0.0181 & 0.0299 \\
\hline$w R_{2}\left(\left|F_{\mathrm{o}}\right| \geq 4 F\right)$ & 0.0394 & 0.0636 \\
\hline$R_{1}$ (all data) & 0.0209 & 0.0323 \\
\hline$w R_{2}$ (all data) & 0.0402 & 0.0660 \\
\hline$S$ & 1.114 & 1.047 \\
\hline$\rho_{\min }, \rho_{\max }\left(\mathrm{e} / \AA^{3}\right)$ & $-0.715,0.883$ & $-0.820,0.928$ \\
\hline ICSD & 1884474 & 1884475 \\
\hline
\end{tabular}


program [15]. Diffraction data for 2 were collected at $293 \mathrm{~K}$ using a Rigaku Oxford Diffraction Xcalibur diffractometer operated with monochromated Mo $K_{\alpha}$ radiation $\left(\lambda\left[\mathrm{Mo} K_{\alpha}\right]=0.71073 \AA\right)$ at $50 \mathrm{kV}$ and $40 \mathrm{~mA}$ and equipped with an Eos CCD area detector. Data were collected with frame widths of $1.0^{\circ}$ in $\omega$ and $\varphi$, and an exposure of $2 \mathrm{~s}$ per frame. Data were integrated and corrected for background, Lorentz, and polarization effects. An empirical absorption correction based on spherical harmonics implemented in the SCALE3 ABSPACK

Table 2: Atomic coordinates, isotropic displacement parameters $\left(\AA^{2}\right)$ and site occupancy factors (s.o.f.) for $\mathrm{Cu}_{2} \mathrm{GaBO}_{5}$ (1) and $\mathrm{Cu}_{2} \mathrm{AlBO}_{5}$ (2).

\begin{tabular}{|c|c|c|c|c|c|}
\hline \multicolumn{6}{|c|}{1} \\
\hline Atom & $x$ & $y$ & $z$ & $U_{e q}$ & s.o.f. \\
\hline $\mathrm{Cu} 1$ & $0.46491(6)$ & $0.71961(2)$ & $0.50724(2)$ & $0.00621(6)$ & 1 \\
\hline $\mathrm{Cu} 2$ & 0.500000 & 0.500000 & 1.000000 & $0.00497(6)$ & 1 \\
\hline $\mathrm{Ga} 3$ & 0.000000 & 0.500000 & 0.500000 & $0.00490(8)$ & 0.66 \\
\hline $\mathrm{Cu} 3$ & 0.000000 & 0.500000 & 0.500000 & $0.00490(8)$ & 0.34 \\
\hline $\mathrm{Cu} 4$ & $0.92862(5)$ & $0.61907(2)$ & $0.77187(2)$ & $0.00601(6)$ & 0.29 \\
\hline $\mathrm{Ga} 4$ & $0.92862(5)$ & $0.61907(2)$ & $0.77187(2)$ & $0.00601(6)$ & 0.71 \\
\hline B1 & $0.9641(5)$ & $0.86426(11)$ & $0.73488(17)$ & $0.0051(2)$ & 1 \\
\hline $\mathrm{O} 1$ & $0.4585(4)$ & $0.64426(8)$ & $0.89925(12)$ & 0.00934(19) & 1 \\
\hline $\mathrm{O} 2$ & $1.0289(3)$ & $0.46141(8)$ & $0.84306(11)$ & $0.00658(16)$ & 1 \\
\hline $\mathrm{O} 3$ & $0.9152(3)$ & $0.76255(8)$ & $0.66705(11)$ & $0.00808(18)$ & 1 \\
\hline $\mathrm{O} 4$ & $0.0074(3)$ & $0.63394(8)$ & $0.38096(12)$ & $0.00685(17)$ & 1 \\
\hline O5 & $0.5519(7)$ & $0.57364(15)$ & $0.6018(2)$ & $0.0068(3)$ & 0.63 \\
\hline O5A & $0.4148(12)$ & $0.5856(3)$ & $0.6286(4)$ & $0.0068(3)$ & 0.37 \\
\hline \multicolumn{6}{|c|}{$\overline{\overline{2}}$} \\
\hline Atom & $x$ & $y$ & $z$ & $U_{e q}$ & s.o.f. \\
\hline $\mathrm{Cu} 1$ & $0.46022(14)$ & $0.71962(4)$ & $0.50700(5)$ & $0.0070(2)$ & 0.88 \\
\hline $\mathrm{Al} 1$ & $0.46022(14)$ & $0.71962(4)$ & $0.50700(5)$ & $0.0070(2)$ & 0.12 \\
\hline $\mathrm{Cu} 2$ & 0.500000 & 0.500000 & 1.000000 & $0.0058(3)$ & 0.86 \\
\hline $\mathrm{Al} 2$ & 0.500000 & 0.500000 & 1.000000 & $0.0058(3)$ & 0.14 \\
\hline $\mathrm{Cu} 3$ & 0.000000 & 0.500000 & 0.500000 & $0.0062(4)$ & 0.34 \\
\hline $\mathrm{Al} 3$ & 0.000000 & 0.500000 & 0.500000 & $0.0062(4)$ & 0.66 \\
\hline $\mathrm{Cu} 4$ & $0.9285(2)$ & $0.61643(6)$ & $0.76921(8)$ & $0.0065(3)$ & 0.33 \\
\hline Al4 & $0.9285(2)$ & $0.61643(6)$ & $0.76921(8)$ & $0.0065(3)$ & 0.67 \\
\hline B1 & $0.9632(14)$ & $0.8634(3)$ & $0.7353(5)$ & $0.0093(9)$ & 1 \\
\hline O1 & $0.4583(10)$ & $0.6440(2)$ & $0.8951(4)$ & $0.0196(8)$ & 1 \\
\hline $\mathrm{O} 2$ & $1.0139(7)$ & $0.4617(2)$ & $0.8422(3)$ & $0.0116(7)$ & 1 \\
\hline $\mathrm{O} 3$ & $0.9147(8)$ & $0.7604(2)$ & $0.6692(3)$ & $0.0129(7)$ & 1 \\
\hline $\mathrm{O} 4$ & $-0.0045(8)$ & $0.6327(2)$ & $0.3830(3)$ & $0.0117(7)$ & 1 \\
\hline O5 & $0.562(2)$ & $0.5695(5)$ & $0.6011(7)$ & $0.0130(12)$ & 0.58 \\
\hline O5A & $0.392(3)$ & $0.5835(7)$ & $0.6295(11)$ & $0.0130(12)$ & 0.42 \\
\hline
\end{tabular}


Table 3: Selected bond lengths in the crystal structure of $\mathrm{Cu}_{2} \mathrm{GaBO}_{5}$ and $\mathrm{Cu}_{2} \mathrm{AlBO}_{5}$.

\begin{tabular}{|c|c|c|c|}
\hline \multicolumn{2}{|c|}{$\mathrm{Cu}_{2} \mathrm{GaBO}_{5}$} & \multicolumn{2}{|c|}{$\mathrm{Cu}_{2} \mathrm{AlBO}_{5}$} \\
\hline Bond & Bond length $(\AA)$ & Bond & Bond length $(\AA)$ \\
\hline$\overline{\mathrm{Cu} 1-\mathrm{O} 1}$ & $1.9172(10)$ & Cu1(Al1)-O1 & $1.919(3)$ \\
\hline $\mathrm{Cu} 1-\mathrm{O} 3$ & $1.9840(10)$ & $\mathrm{Cu} 1(\mathrm{Al1})-\mathrm{O} 3$ & $1.977(2)$ \\
\hline $\mathrm{Cu} 1-\mathrm{O} 4$ & $2.4241(11)$ & $\mathrm{Cu} 1(\mathrm{Al1})-\mathrm{O} 4$ & $2.366(3)$ \\
\hline $\mathrm{Cu} 1-\mathrm{O} 4$ & $2.0087(10)$ & $\mathrm{Cu} 1(\mathrm{Al1})-\mathrm{O} 4$ & $1.995(3)$ \\
\hline $\mathrm{Cu} 1-\mathrm{O} 5$ & 1.9591(18) & $\mathrm{Cu} 1(\mathrm{Al1})-\mathrm{O} 5$ & $1.983(6)$ \\
\hline Cu1-05A & $1.987(3)$ & $\mathrm{Cu} 1$ (Al1)-O5A & $2.000(9)$ \\
\hline$\langle\mathrm{Cu} 1-\mathrm{O}\rangle$ & 2.047 & $\langle\mathrm{Cu} 1(\mathrm{Al} 1)-\mathrm{O}\rangle$ & 2.040 \\
\hline $\mathrm{Cu} 2-\mathrm{O} 1$ & $2 \times 1.9627(10)$ & $\mathrm{Cu} 2(\mathrm{Al} 2)-\mathrm{O} 1$ & $2 \times 1.957(3)$ \\
\hline $\mathrm{Cu} 2-\mathrm{O} 2$ & $2 \times 1.9935(10)$ & $\mathrm{Cu} 2(\mathrm{Al} 2)-\mathrm{O} 2$ & $2 \times 2.004(3)$ \\
\hline $\mathrm{Cu} 2-\mathrm{O} 2$ & $2 \times 2.4082(11)$ & $\mathrm{Cu} 2(\mathrm{Al} 2)-\mathrm{O} 2$ & $2 \times 2.344(3)$ \\
\hline$\langle\mathrm{Cu} 2-\mathrm{O}\rangle$ & 2.122 & & 2.102 \\
\hline $\mathrm{Cu} 3(\mathrm{Ga} 3)-\mathrm{O} 4$ & $2 \times 1.9569(10)$ & $\mathrm{Cu} 3(\mathrm{Al} 2)-\mathrm{O} 4$ & $2 \times 1.909(3)$ \\
\hline Cu3(Ga3)-O5 & $2 \times 2.0485(18)$ & $\mathrm{Cu} 3(\mathrm{Al} 2)-\mathrm{O} 5$ & $2 \times 1.927(7)$ \\
\hline Cu3(Ga3)-O5 & $2 \times 2.003(2)$ & $\mathrm{Cu} 3(\mathrm{Al} 2)-\mathrm{O} 5$ & $2 \times 2.022(6)$ \\
\hline $\mathrm{Cu} 3(\mathrm{Ga} 3)-\mathrm{O} 5 \mathrm{~A}$ & $2 \times 1.939(3)$ & $\mathrm{Cu} 3(\mathrm{Al} 2)-\mathrm{O} 5 \mathrm{~A}$ & $2 \times 1.869(10)$ \\
\hline$\langle\mathrm{Cu} 3(\mathrm{Ga} 3)-\mathrm{O}\rangle$ & 1.986 & $\langle\mathrm{Cu} 3(\mathrm{Al} 3)-\mathrm{O}\rangle$ & 1.932 \\
\hline $\mathrm{Cu} 4(\mathrm{Ga} 4)-\mathrm{O} 1$ & $2.0419(13)$ & $\mathrm{Cu} 4(\mathrm{Al} 4)-\mathrm{O} 1$ & $2.007(3)$ \\
\hline $\mathrm{Cu} 4(\mathrm{Ga} 4)-\mathrm{O} 1$ & $1.9287(11)$ & $\mathrm{Cu} 4(\mathrm{Al} 4)-\mathrm{O} 1$ & $1.901(3)$ \\
\hline $\mathrm{Cu} 4(\mathrm{Ga} 4)-\mathrm{O} 2$ & $2.0071(10)$ & $\mathrm{Cu} 4(\mathrm{Al} 4)-\mathrm{O} 2$ & $1.953(3)$ \\
\hline $\mathrm{Cu} 4(\mathrm{Ga} 4)-\mathrm{O} 3$ & $1.9756(10)$ & $\mathrm{Cu} 4(\mathrm{Al} 4)-\mathrm{O} 3$ & $1.936(3)$ \\
\hline $\mathrm{Cu} 4(\mathrm{Ga} 4)-\mathrm{O} 5$ & $1.9357(18)$ & $\mathrm{Cu} 4(\mathrm{Al} 4)-\mathrm{O} 5$ & $1.891(7)$ \\
\hline $\mathrm{Cu} 4(\mathrm{Ga} 4)-\mathrm{O} 5 \mathrm{~A}$ & $2.203(4)$ & $\mathrm{Cu} 4(\mathrm{Al} 4)-\mathrm{O} 5 \mathrm{~A}$ & $1.996(10)$ \\
\hline $\mathrm{Cu} 4(\mathrm{Ga} 4)-\mathrm{O} 5 \mathrm{~A}$ & $1.991(3)$ & $\mathrm{Cu} 4(\mathrm{Al} 4)-\mathrm{O} 5 \mathrm{~A}$ & 2.095(10) \\
\hline$\langle\mathrm{Cu} 4(\mathrm{Ga} 4)-\mathrm{O}\rangle$ & 2.012 & $\langle\mathrm{Cu} 4(\mathrm{Al} 4)-\mathrm{O}\rangle$ & 1.968 \\
\hline $\mathrm{B} 1-\mathrm{O} 2$ & $1.3754(17)$ & $\mathrm{B} 1-\mathrm{O} 2$ & $1.374(5)$ \\
\hline B1-O3 & $1.3711(18)$ & $\mathrm{B} 1-\mathrm{O} 3$ & $1.362(5)$ \\
\hline B1-O4 & $1.3717(19)$ & $\mathrm{B} 1-\mathrm{O} 4$ & $1.376(5)$ \\
\hline$\langle\mathrm{B} 1-\mathrm{O}\rangle$ & 1.373 & $\langle\mathrm{~B} 1-\mathrm{O}\rangle$ & 1.371 \\
\hline
\end{tabular}

algorithm was applied in CrysAlisPro program [16]. The unit cell parameters of 1 and 2 (Table 1 ) were determined and refined by least-squares techniques. The structures were solved by direct methods and refined using the SHELX program [17] incorporated in the OLEX2 program package [18]. The final models included coordinates, see Table 2, and anisotropic displacement parameters for all atoms. Selected interatomic distances are listed in Table 3. It should be noted that in some cases highly redundant XRD data (full sphere and $I / \sigma>$ 
30-40) allow refining the site occupancy factors for close, even neighbor, elements from the Periodic Table [19]. Supplementary crystallographic data have been deposited in the Inorganic Crystal Structure Database (CSD 1884474 (1) and 1884475 (2)) and can be obtained from the Cambridge Crystallographic Data via https://www.ccdc.cam.ac.uk/structures/.

\subsection{Magnetic susceptibility}

The magnetization $M$ of single crystalline samples was measured on the commercial Physical Properties Measurements System (PPMS-9 device) within a temperature range $2 \mathrm{~K} \leq T \leq 400 \mathrm{~K}$ in zero-field-cooled (ZFC) and fieldcooled (FC) regimes in magnetic fields $H$ up to $9 \mathrm{~T}$. Figure 1 shows the FC magnetic susceptibility $\chi=M / H$ of $\mathrm{Cu}_{2} \mathrm{GaBO}_{5}$ and $\mathrm{Cu}_{2} \mathrm{AlBO}_{5}$ ludwigites as a function of temperature for the magnetic field applied parallel and perpendicular to the crystallographic $a$-axis. The temperature dependence of the derivative magnetic susceptibility $\partial \chi / \partial T=\partial M / \partial H$ measured in the FC regime at low temperatures is presented in the inset of Fig. 1. The magnetic phase transition temperature was obtained as the susceptibility anomaly which corresponds to the maximum of the derivative magnetic susceptibility: $T=4.1-5.5 \mathrm{~K}$ for $\mathrm{Cu}_{2} \mathrm{GaBO}_{5}$, in agreement with our published results [20], and $T=2.08 \mathrm{~K}$ for $\mathrm{Cu}_{2} \mathrm{AlBO}_{5}$, respectively (Fig. 1). The obtained temperature for $\mathrm{Cu}_{2} \mathrm{GaBO}_{5}$ is different from the previously observed Néel temperature $T_{\mathrm{N}}=3.4 \mathrm{~K}$ [9]. The difference in Néel temperatures can result from the quality of the sample or from the destruction of the AFM order by a sufficiently weak magnetic field.

It is possible to unambiguously indicate the type of magnetic phase transition only by studying the temperature dependence of the magnetization on alternating current. Figure 2 presents the temperature dependence of the AC magnetic susceptibility measured with $H=4 \mathrm{Oe}$. The presence of a peak in the real part of the magnetization and its absence in the imaginary part of the magnetization indicates the transition from an antiferromagnetic to the paramagnetic state for $\mathrm{Cu}_{2} \mathrm{GaBO}_{5}$ single crystal at $4.1 \mathrm{~K}$. The magnetic field dependence of the magnetization for $\mathrm{Cu}_{2} \mathrm{GaBO}_{5}$ and $\mathrm{Cu}_{2} \mathrm{AlBO}_{5}$ is presented in Fig. 3 ,

\subsection{Specific heat}

The specific heat was measured by the relaxation method using a Physical Property Measurement System (PPMS) (Quantum Design) in the temperature range $1.8 \mathrm{~K}<T<400 \mathrm{~K}$ and in magnetic fields up to $13.8 \mathrm{~T}$. Figure 4 shows the specific heat $C(T)$ as a function of temperature for $\mathrm{Cu}_{2} \mathrm{GaBO}_{5}$ and $\mathrm{Cu}_{2} \mathrm{AlBO}_{5}$ ludwigites measured in zero magnetic field. An anomaly was observed in the $C(T)$ data at $T \approx 4 \mathrm{~K}$ and $T \approx 3 \mathrm{~K}$ in $\mathrm{Cu}_{2} \mathrm{GaBO}_{5}$ and $\mathrm{Cu}_{2} \mathrm{AlBO}_{5}$, respectively (inset in Fig. $4 \mathrm{a}$ ). The obtained values are close to the corresponding anomalies in the $\partial \chi / \partial T$ vs. $T$ curves. In the accessible magnetic-field range, the anomaly is field dependent, indicating the broadening and the decreasing of the peak intensity with increasing of the applied magnetic field (Fig. 5). This suggests that the small magnetic field (on the order of $2.5 \mathrm{~T}$ ) destroys of the long-range AFM order. 

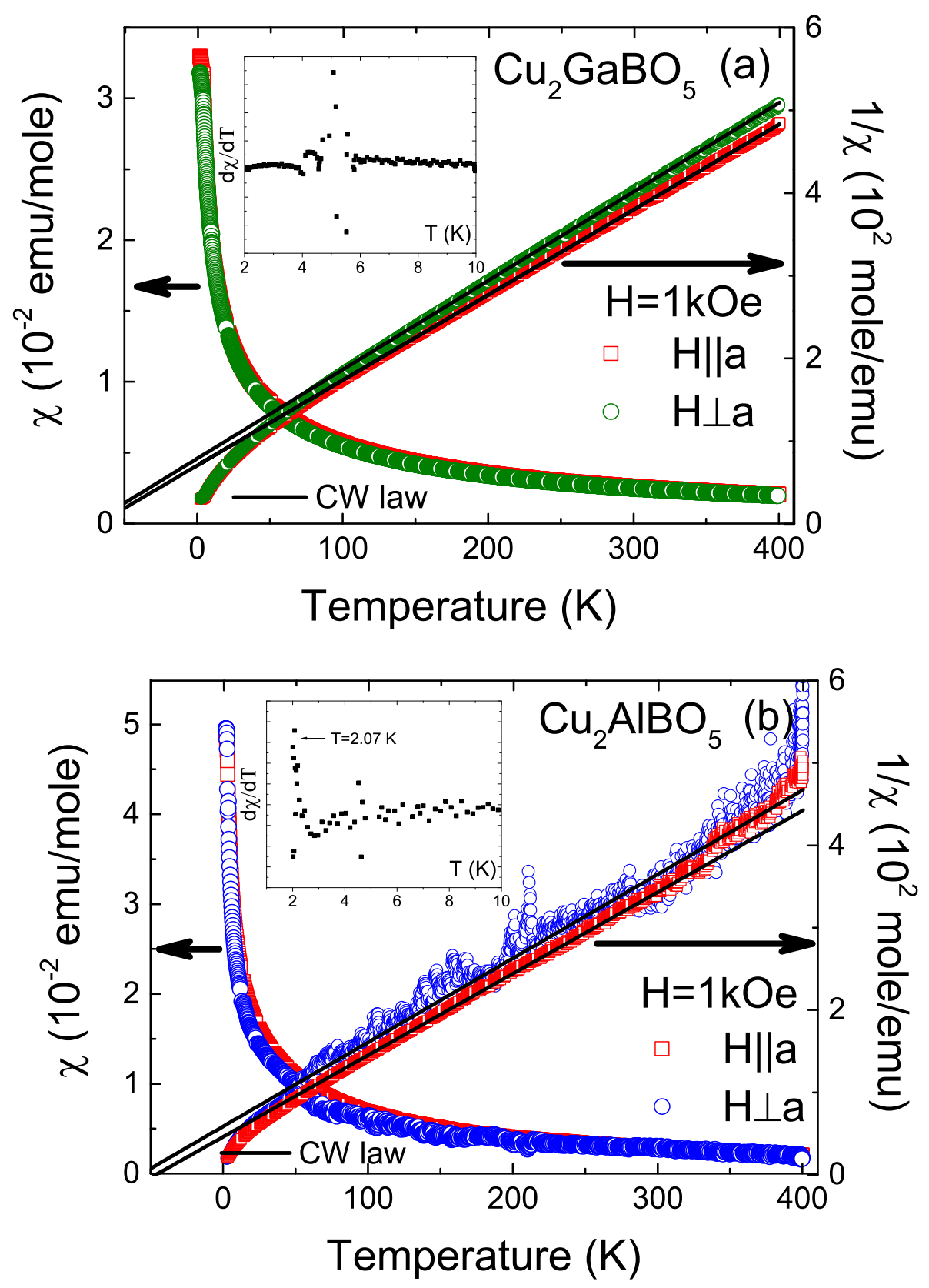

Figure 1: Temperature dependencies of the magnetic susceptibility and inverse magnetic susceptibility in (a) $\mathrm{Cu}_{2} \mathrm{GaBO}_{5}$ and (b) $\mathrm{Cu}_{2} \mathrm{AlBO}_{5}$ ludwigites measured in $\mathrm{FC}$ regime in the magnetic field $(H=1 \mathrm{kOe})$ applied parallel and perpendicular to the crystallographic $a$ axis. The inset shows temperature dependence of the derivative magnetic susceptibility at low temperatures.

\section{Discussion}

The unit cell of the investigated ludwigites contains $Z=4$ formula units, so the unit cell can contain up to twelve divalent cations $\left(\mathrm{Cu}^{2+}, 3 d^{9}\right)$ with spin $S=1 / 2$. Each magnetic $\mathrm{Cu}^{2+}$ ion is surrounded by six oxygen ions form- 
ing a strongly distorted octahedron. We can identify four types of structurally nonequivalent oxygen octahedra, which correspond to four atomic sites of copper ions. Four types of oxygen octahedra form zigzag walls which are presented in Fig. 6. Interatomic distances between cations and anions are given in Table 3. The obtained here crystallographic parameters are close to the previously published parameters for $\mathrm{Cu}_{2} \mathrm{GaBO}_{5}$ ludwigites. In addition to Refs. [22] and [14] we have analyzed the selective distribution of cations on metal sites. The distinctive features of the structures of $\mathrm{Cu}_{2} \mathrm{GaBO}_{5}$ (1) and $\mathrm{Cu}_{2} \mathrm{AlBO}_{5}$ (2) are the selective distribution of $\mathrm{Cu}, \mathrm{Ga}$ and $\mathrm{Al}$ cations (Table 2). M1, M2, M3 and M4 sites in the structure are presented in Fig. 4. M1 and M2 sites are fully occupied by $\mathrm{Cu}$ atoms (site-scattering factors $=28.7$ and $28.8 \mathrm{epfu}$ ); whereas M3 and M4 sites in the structure of $\mathbf{1}$ are predominately occupied by Ga atoms with less amount of $\mathrm{Cu}(\mathrm{Ga}: \mathrm{Cu}=0.66: 0.34$ and 0.71:0.29, respectively). M1 and M2 sites are predominately occupied by $\mathrm{Cu}$ atoms with significantly less amount of $\mathrm{Al}$ (Cu:Al = 0.88:0.12 and 0.86:0.14, respectively); whereas $\mathrm{M} 3$ and M4 sites in the structure of $\mathbf{2}$ are predominately occupied by $\mathrm{Al}$ atoms with less amount of $\mathrm{Cu}(\mathrm{Cu}: \mathrm{Al}=0.34: 0.66$ and 0.33:0.67, respectively). The presence of copper-ion chains in the structure $1\left(\mathrm{Cu}_{2} \mathrm{GaBO}_{5}\right)$ can affect the magnetic properties of the compound.

From magnetic susceptibility measurements (Fig. 1) we can see that for both samples $\chi$ can be well fitted by the Curie-Weiss law $\chi=C /(T-\Theta)$ above $50 \mathrm{~K}$, that is confirmed by the linear temperature dependence of the

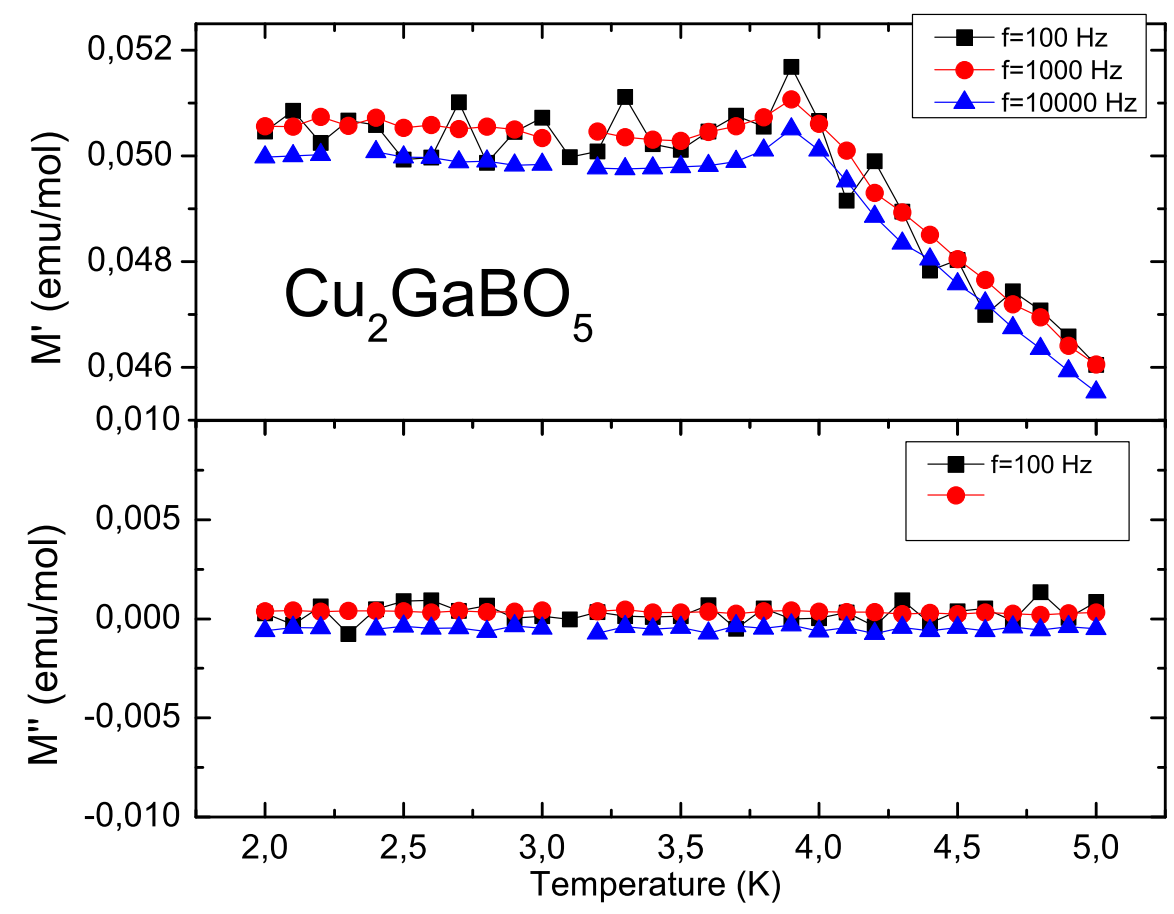

Figure 2: Temperature dependence of the real and imaginary parts of the AC magnetization as a function of frequency at low temperatures for $\mathrm{H}=4$ Oe in $\mathrm{Cu}_{2} \mathrm{GaBO}_{5}$. 


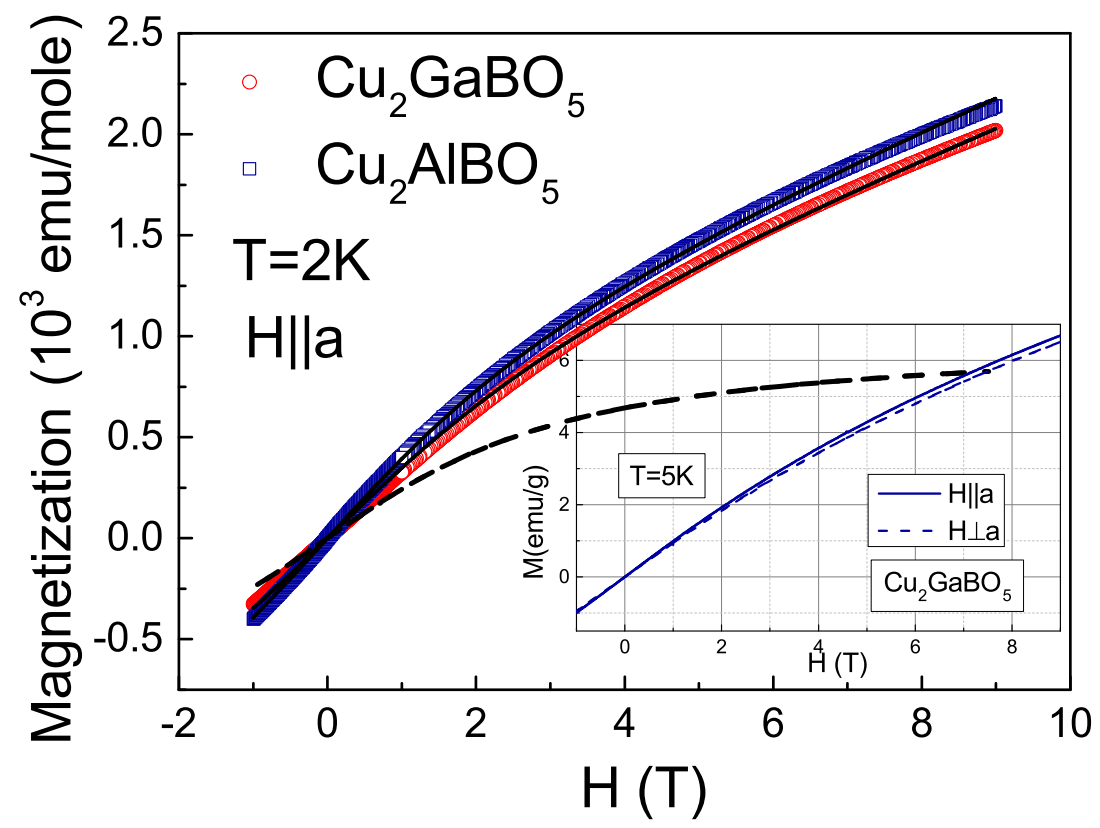

Figure 3: Magnetic field dependence of the magnetization measured at low temperatures. The solid lines are sums of the magnetic and paramagnetic contributions. The dashed line is the magnetic contribution.

inverse magnetic susceptibility (Fig. 1). The fitting parameters-Curie constant $C$ and Curie-Weiss temperature $\Theta$ are summarized in Table 4. The CurieWeiss temperature $\Theta$ is negative, which indicates that exchange interactions between copper spins are predominantly antiferromagnetic in the investigated samples. The effective magnetic moment estimated as $\mu_{\text {eff }}=\sqrt{3 k_{\mathrm{B}} C / N_{\mathrm{A}}}$ is $(2.72 \div 2.78) \mu_{\mathrm{B}}$ and $(2.81 \div 2.85) \mu_{\mathrm{B}}$ for the two copper ions in the formula unit of $\mathrm{Cu}_{2} \mathrm{GaBO}_{5}$ and $\mathrm{Cu}_{2} \mathrm{AlBO}_{5}$, respectively. Theoretically, the effective magnetic moment of copper ions can be evaluated as:

$$
\mu_{\text {eff }}\left(\mathrm{Cu}^{2+}\right)=g \sqrt{N_{S} S(S+1)}=2.69 \mu_{\mathrm{B}} .
$$

Since only the copper spins contribute to the magnetization, we use the value $g=2.2$ which is characteristic for copper ions in the octahedron environment

Table 4: Fitting parameters of the temperature dependence of the magnetic susceptibility for some compounds of the ludwigite family. The magnetic ordering temperature $T_{\mathrm{MO}}$ and the fit parameter $\Theta$ are given in $\mathrm{K}$; Curie constants are given in emu $\cdot \mathrm{K} / \mathrm{mol}$.

\begin{tabular}{l|lrrccc}
\hline \hline & $T_{\mathrm{N}}$ & $\Theta_{\| a}$ & $\Theta_{\perp a}$ & $C_{\| a}$ & $C_{\perp a}$ & Ref. \\
\hline $\mathrm{Cu}_{2} \mathrm{GaBO}_{5}$ & 4.0 & -69 & -74 & 0.97 & 0.93 & this work \\
$\mathrm{Cu}_{2} \mathrm{AlBO}_{5}$ & 2.8 & -47 & -58 & 1.01 & 0.98 & this work \\
& & & & & & \\
$\mathrm{Cu}_{2} \mathrm{GaBO}_{5}$ & 3.4 & -68 & -54 & & & {$[9]$} \\
$\mathrm{FeMg}_{2} \mathrm{BO}_{5}$ & 8 & -170 & -170 & & & {$[21]$} \\
\hline \hline
\end{tabular}



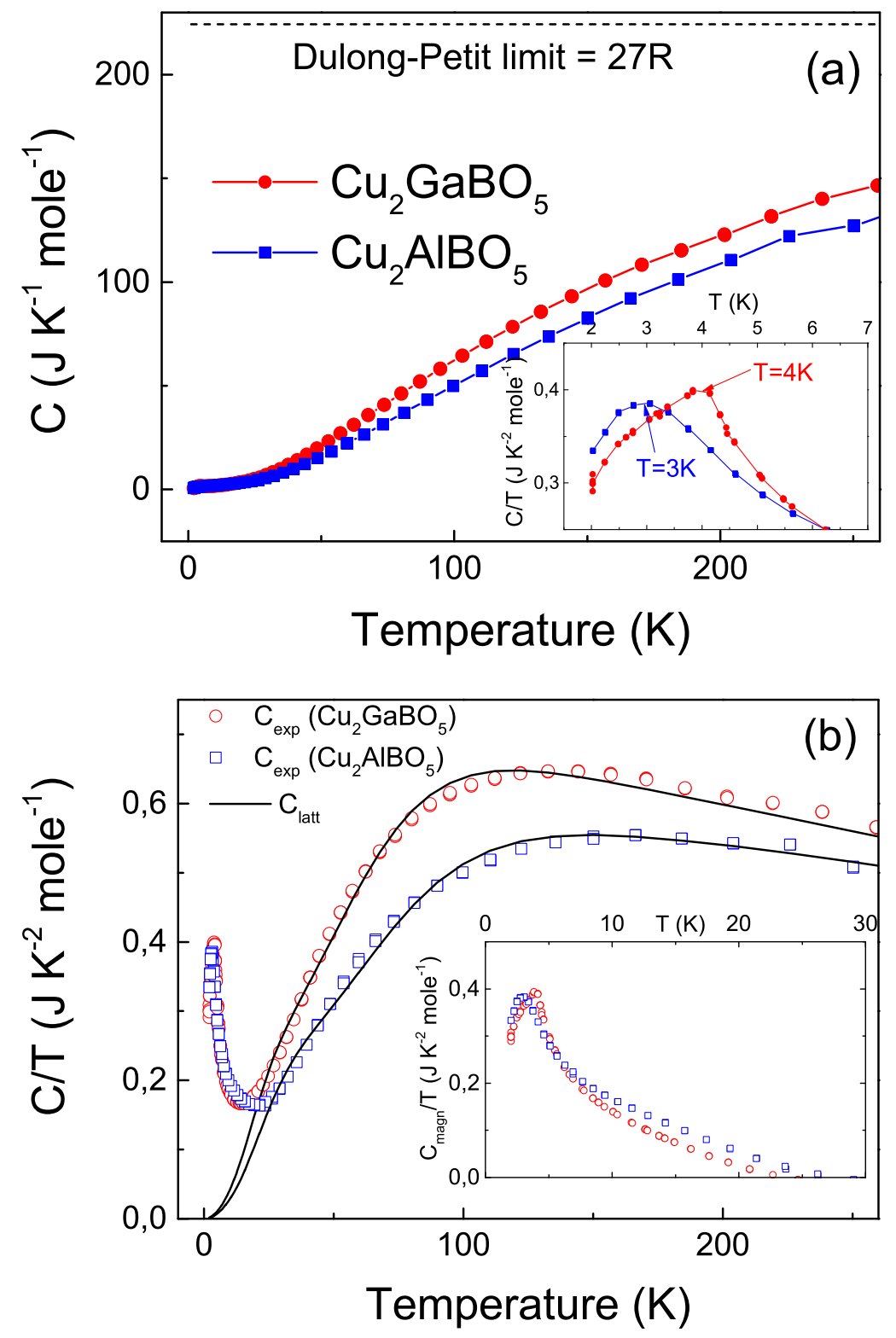

Figure 4: (a) Temperature dependence of the specific heat $C(T)$ of $\mathrm{Cu}_{2} \mathrm{GaBO}_{5}$ and $\mathrm{Cu}_{2} \mathrm{AlBO}_{5}$ measured in zero magnetic field. Inset: Specific heat of $\mathrm{Cu}_{2} \mathrm{GaBO}_{5}$ and $\mathrm{Cu}_{2} \mathrm{AlBO}_{5}$ in the temperature range $2 \mathrm{~K} \leq T \leq 10 \mathrm{~K}$. (b) Specific heat in representation $C / T$ as a function of $T$, the black solid line is the fitting curve (see details in the text) Inset: low-temperature magnetic specific heat $C_{\mathrm{M}} / T$ versus $T$ in zero external magnetic field after subtracting the calculated lattice contribution.

formed by oxygen ions and $S=1 / 2$ for $\mathrm{Cu}^{2+}, N_{S}=2$ is the number of ions with spin $S$ in the chemical formula unit. We can see that the experimentally obtained values of the effective magnetic moments are close to the theoretically predicted ones. As there are 4 inequivalent $\mathrm{Cu}$ sites, all of them could have different $g$-factor values and different magnetic moments. It should be perhaps made clear that these values refer to some average moments. The effective 


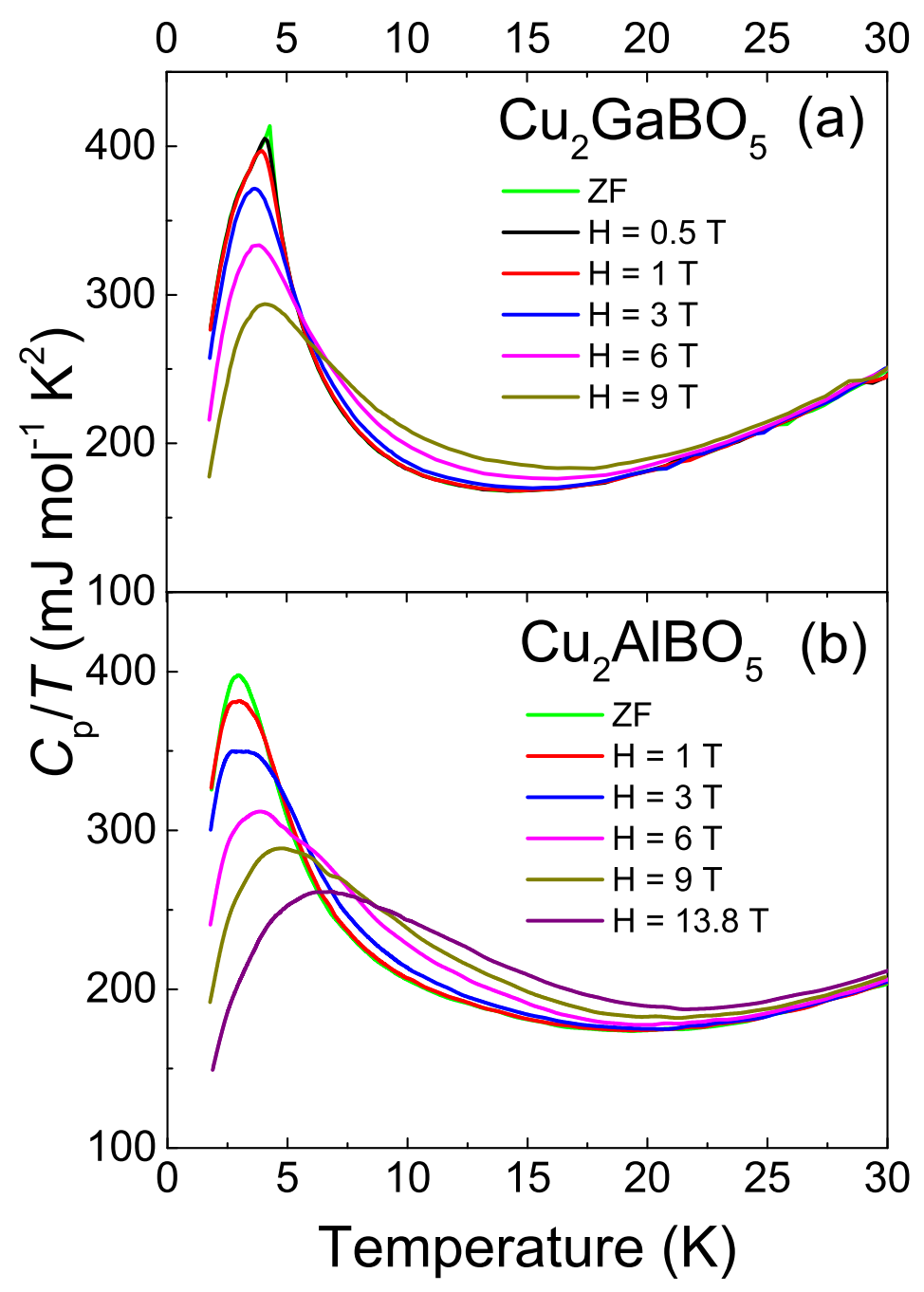

Figure 5: Magnetic contribution to the specific heat $C_{\mathrm{M}}(T) / T$ of (a) $\mathrm{Cu}_{2} \mathrm{GaBO}_{5}$ and (b) $\mathrm{Cu}_{2} \mathrm{AlBO}_{5}$ measured both on field cooling (FC) and in zero magnetic field.

magnetic moments for $\mathrm{Cu}_{2} \mathrm{AlBO}_{5}$ is higher than for $\mathrm{Cu}_{2} \mathrm{GaBO}_{5}$. At lowest temperatures, we can also see that the susceptibility $\chi$ in $\mathrm{Cu}_{2} \mathrm{AlBO}_{5}$ approaches a value of $5.58 \times 10^{-2} \mathrm{emu} / \mathrm{mol}$, that is 1.5 times higher than for $\mathrm{Cu}_{2} \mathrm{GaBO}_{5}$ (Fig. 1). This indicates a more significant paramagnetic contribution from the random distribution of copper ions and defects in the samples. The number of defects was changed from sample to sample.

The dependencies of magnetization on the magnetic field were measured on $\mathrm{Cu}_{2} \mathrm{GaBO}_{5}$ and $\mathrm{Cu}_{2} \mathrm{AlBO}_{5}$, and it was shown that the paramagnetic component for $\mathrm{Cu}_{2} \mathrm{AlBO}_{5}$ was slightly larger than in $\mathrm{Cu}_{2} \mathrm{GaBO}_{5}$. Magnetic field dependencies of the magnetization in these compound at temperature $2 \mathrm{~K}$, are presented in Fig. 3. At $2 \mathrm{~K}$ the magnetizations have been described as a sum of two contributions (see Fig. 3) by the formula $B=B_{\mathrm{m}}+B_{\mathrm{pm}}$. There $B_{\mathrm{m}}=\frac{2 B_{\mathrm{S}}}{\pi} \tan ^{-1}\left[\left(H \pm H_{\mathrm{C}}\right) / H_{T}\right]$ is the magnetic contribution [23], with $B_{\mathrm{S}}$ is the 


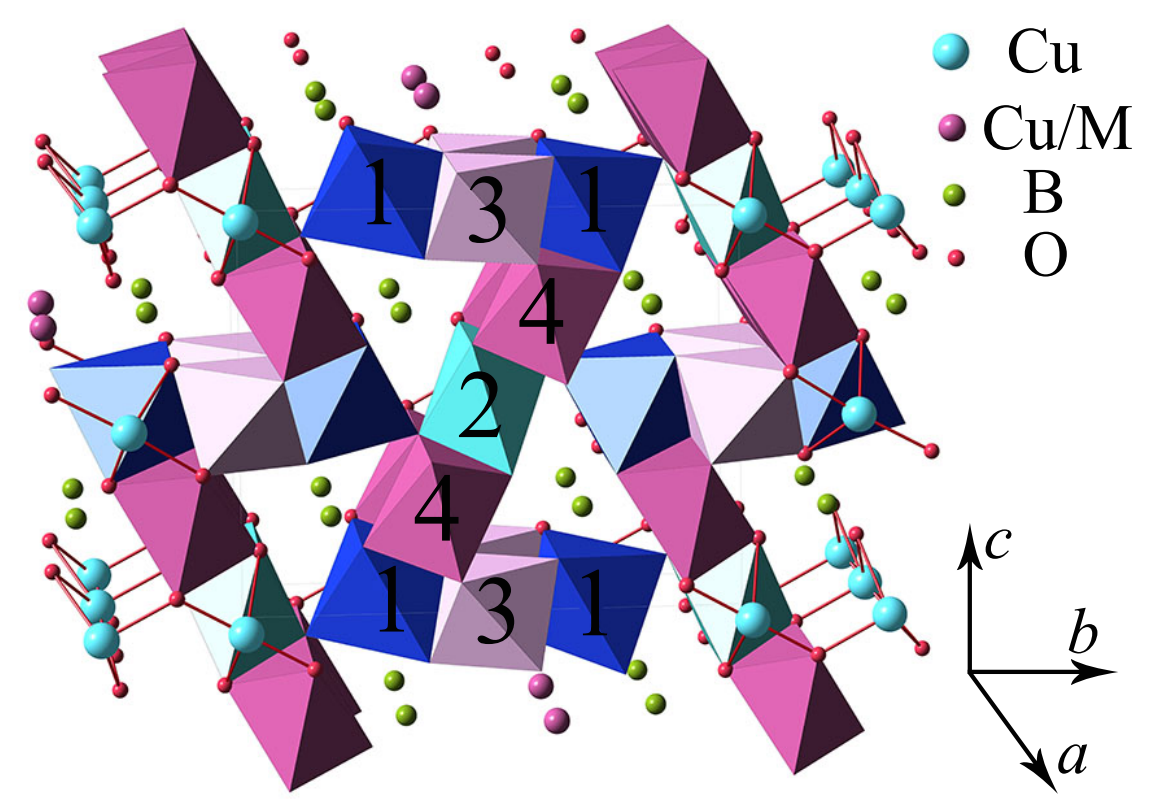

Figure 6: Crystal structure of $\mathrm{Cu}_{2} \mathrm{MBO}_{5}(M=\mathrm{Ga}, \mathrm{Al})$ ludwigites. Dark blue and light blue octahedrons surround $\mathrm{Cu} 1 / M$ and $\mathrm{Cu} 2 / M$ positions, light magenta and dark magenta octahedrons surround $\mathrm{Cu3} / M$ and $\mathrm{Cu} 4 / M$ positions, respectively.

saturation magnetization and $H_{T}$ is the inner local field of uniaxial anisotropy, $H_{\mathrm{C}}$ is the coercive field and $B_{\mathrm{pm}}=\chi H$ is the paramagnetic contribution from defects. Fitting parameters are equal to $B_{\mathrm{S}}=0.1 \mathrm{~T}, B_{\mathrm{S}}=0.095 \mathrm{~T} ; H_{T}=2.5 \mathrm{~T}$, $H_{T}=2.8 \mathrm{~T} ; \chi=1.5 \mathrm{emu} /(\mathrm{K} \cdot \mathrm{mol}), \chi=1.4 \mathrm{emu} /(\mathrm{K} \cdot \mathrm{mol})$; and $H_{\mathrm{C}}=0$ for $\mathrm{Cu}_{2} \mathrm{GaBO}_{5}$ and $\mathrm{Cu}_{2} \mathrm{AlBO}_{5}$, respectively. As follows from our description, the weak external magnetic field $2.5 \mathrm{~T}$ destroys the long magnetic order and when the magnetic field is increased more, the spins have been polarized along the external magnetic field.

In the $\mathrm{Cu}_{2} \mathrm{GaBO}_{5}$ compound gallium ions are nonmagnetic and only magnetic moments of copper ions are ordered with $T_{\mathrm{N}}=4 \mathrm{~K}$. Temperature dependencies of image and real magnetization for this compound are displayed in Fig. 2. As expected for the AFM structure, the peak is absent in the imaginary part [13].

As we know from X-ray diffraction measurements, there are linear chains of $\mathrm{Cu}^{2+}$ ions in the M1 and M2 sites of the investigated sample, located along the crystallographic $a$-axis (Fig. 6). Typically for 1D antiferromagnetic Heisenberg chains of localized spins the magnetic susceptibility exhibits a maximum at a temperature comparable to the intrachain exchange, as it was in the case of the copper-based compounds $\mathrm{CuTe}_{2} \mathrm{O}_{5}$ [24], $\mathrm{CuTa}_{2} \mathrm{O}_{6}$ [25], $\mathrm{Na}_{2} \mathrm{Cu}_{2} \mathrm{TeO}_{6}$ [26], $\mathrm{Na}_{3} \mathrm{Cu}_{2} \mathrm{SbO}_{6}$ [27], where the temperature dependence of the susceptibility could be approximated using the model of an AFM spin $S=1 / 2$ chain [28]. As we can see from Fig. 1 , the magnetic susceptibility of $\mathrm{Cu}_{2} \mathrm{GaBO}_{5}$ and $\mathrm{Cu}_{2} \mathrm{AlBO}_{5}$ does not exhibit a broad maximum but displays a sharp cusp at 4.0 and $2.8 \mathrm{~K}$, respectively. 
Also in contrast to the investigated here bimetallic monomagnetic ludwigites with the temperature of the AFM ordering $T_{\mathrm{N}}=2-4 \mathrm{~K}$ and previously investigated $\mathrm{FeMg}_{2} \mathrm{BO}_{5}$ with the Néel temperature $T_{\mathrm{N}} \simeq 8 \mathrm{~K}$ [21] the magnetic phase transition in bimagnetic ludwigites was observed at much higher temperatures: $92 \mathrm{~K}-$ for $\mathrm{Cu}_{2} \mathrm{MnBO}_{5}$ [2], $81-92 \mathrm{~K}-$ for $\mathrm{Mn}_{3-x} \mathrm{Ni}_{x} \mathrm{BO}_{5}$ [4]. For iron-containing bimagnetic ludwigites $\left(M_{2} \mathrm{FeBO}_{5}, M=\mathrm{Ni}, \mathrm{Cu}, \mathrm{Co}\right)$ it was observed that the ordering temperatures of the $\mathrm{Fe}^{3+}$ sub-system in each compound is higher than that of the respective $M$ sub-system [5, 29, 7, 8]. The magnetic phase transition temperature in homometallic magnetic ludwigites is also rather high: $42 \mathrm{~K}$ - for $\mathrm{Co}_{3} \mathrm{BO}_{5}$ [30] and $112 \mathrm{~K}$ - the temperature of the partial magnetic transition for $\mathrm{Fe}_{3} \mathrm{BO}_{5}$, while the whole system of $\mathrm{Fe}$ moments become magnetically ordered at $T_{\mathrm{N}}=70 \mathrm{~K}[31,30]$.

The investigations of thermodynamic properties showed that at $300 \mathrm{~K}$ the specific heat is still considerably lower than the expected high-temperature value $3 R s=225 \mathrm{~J} /(\mathrm{mol} \cdot \mathrm{K})$ for the phonon contribution given by the DulongPetit law (Fig. 4), indicating contributions to the phonon-density of states from higher-lying lattice modes. Here, $R$ denotes the gas constant and $s$ the number of atoms per formula unit. We assume that the total heat capacity originates from two different contributions, a lattice contribution $C_{\text {latt }}$ due to acoustic and optical phonons and a magnetic contribution $C_{\mathrm{M}}$ corresponding to the thermal population of excited magnetic states. We expect that the magnetic contribution is small compared to the lattice contribution as it was in the case of other copper-based low-dimensional systems [32, 33]. The straightforward method to unambiguously extract the magnetic contribution from the experimental data is difficult to realize because a specific heat data for non-magnetic reference material $\left(\mathrm{Mg}_{2} \mathrm{AlBO}_{5}\right.$ [34] or $\left.\mathrm{Zn}_{2} \mathrm{AlBO}_{5}\right)$ is not available. The lattice contribution $\mathrm{C}_{\text {latt }}$ was approximated following standard procedures [35] with a minimized set of fit parameters only using a sum of one isotropic Debye $\left(C_{\mathrm{D}}\right)$ accounting for the 3 acoustic phonon branches and two isotropic Einstein terms $\left(C_{\mathrm{E} 1}, C_{\mathrm{E} 2}\right)$ averaging the $3 s-3=24$ optical phonon branches:

$$
\begin{array}{r}
C=C_{\text {latt }}+C_{\mathrm{M}}, \\
C_{\text {latt }}=\alpha_{\mathrm{D}} \cdot C_{\mathrm{D}}+\alpha_{\mathrm{E} 1} \cdot C_{\mathrm{E} 1}+\alpha_{\mathrm{E} 2} \cdot C_{\mathrm{E} 2} .
\end{array}
$$

For further reducing the number of free fit parameters, the ratio between these terms was fixed to $\alpha_{\mathrm{D}}: \alpha_{\mathrm{E} 1}: \alpha_{\mathrm{E} 2}=1: 4: 4$ to account for the $3 s=27$ degrees of freedom per formula unit. For $s=9$ atoms formula unit, the ratio between acoustical (Debye) and optical (Einstein) contributions is naturally fixed as $1: 8$. The weight distribution between the optical contributions is chosen in such a way that the degrees of freedom have been equally distributed between the higher Einstein modes. The resulting fit curve (solid line in Fig. 3b) describes the data satisfactorily. For the respective Debye and Einstein temperatures we obtained $\Theta_{\mathrm{D}}=166.3 \mathrm{~K}, \Theta_{\mathrm{E} 1}=338.4 \mathrm{~K}, \Theta_{\mathrm{E} 2}=1009.3 \mathrm{~K}-$ for $\mathrm{Cu}_{2} \mathrm{GaBO}_{5}$ and $\Theta_{\mathrm{D}}=189.5 \mathrm{~K}, \Theta_{\mathrm{E} 1}=401.3 \mathrm{~K}, \Theta_{\mathrm{E} 2}=1108.2 \mathrm{~K}-$ for $\mathrm{Cu}_{2} \mathrm{AlBO}_{5}$. As one can see, the existence of high-frequency modes at $1009.3 \mathrm{~K}$ or $1108.2 \mathrm{~K}$ 
agrees well with the fact that the Dulong-Petit value is approached only far above room temperature.

The magnetic contribution to the specific heat $C_{\mathrm{M}}$ was obtained as the difference between the experimentally measured data and the calculated by the Eq. 2 lattice contribution $C_{\mathrm{M}}=C_{\text {exp }}-C_{\text {latt }}$. The inset in Fig. $4 \mathrm{~b}$ shows the obtained a such a way the magnetic contribution for zero magnetic field. The temperature dependence of $C_{\mathrm{M}}$ for different values of the applied magnetic field is given in Fig. 5. The magnetic contribution in $\mathrm{Cu}_{2} \mathrm{AlBO}_{5}$ has the broad maximum, its width increases with increasing of the magnetic field (Fig. 6a). We suggest that such a behavior of the specific heat together with the sharp peak in $\chi-T$ curve (Fig. $1 \mathrm{~b}$ ) and the random distribution of copper ions in the crystal structure is due to the AFM transition in $\mathrm{Cu}_{2} \mathrm{AlBO}_{5}$ at $T_{\mathrm{N}} \approx 3 \mathrm{~K}$. Previously, the shift of the broad maximum in the temperature dependence of the magnetic specific heat together with the anomaly in $\chi-T$ curve were observed [36, 37, 38].

For $\mathrm{Cu}_{2} \mathrm{GaBO}_{5}$ we suggest the presence of one type of the extended phase transition. The transition begins to be observed at $T=4.0 \mathrm{~K}$ in the AFM longrange oder and the sample is completely ordered to the temperature $T_{\mathrm{N}} \approx 3 \mathrm{~K}$, we attribute this to the random distribution of copper and gallium ions on M3 and M4 positions (see Fig. 6). The long-range magnetic order is easily destroyed by a magnetic field larger than $2.5 \mathrm{~T}$, but short-range order regions are preserved. For $\mathrm{Cu}_{2} \mathrm{AlBO}_{5}$ we suggest the presence of one type of AFM phase transition. Probably, this is the ordering of AFM clusters formed near a nonmagnetic impurity (aluminum). Similar behavior was observed in quasione-dimensional magnetic $\mathrm{CuGeO}_{3}$ with impurity and defects [39, 40].

\section{Summary}

Here we presented the investigations of single crystals of $\mathrm{Cu}_{2} \mathrm{GaBO}_{5}$ and $\mathrm{Cu}_{2} \mathrm{AlBO}_{5}$ oxyborates with the ludwigite structure synthesized by the flux technique. The distinctive features of the investigated structures are the selective distribution of $\mathrm{Cu}, \mathrm{Ga}$ and $\mathrm{Al}$ cations. The unit cell of $\mathrm{Cu}_{2} \mathrm{GaBO}_{5}$ and $\mathrm{Cu}_{2} \mathrm{AlBO}_{5}$ contains four nonequivalent crystallographic sites of metal ions. Two sites in the structure of $\mathrm{Cu}_{2} \mathrm{GaBO}_{5}$ are predominantly occupied by $\mathrm{Ga}$ atoms with less amount of $\mathrm{Cu}(\mathrm{Ga}: \mathrm{Cu}=0.71: 0.29$ and 0.66:0.34, respectively); whereas other sites are fully occupied by $\mathrm{Cu}$ atoms. For $\mathrm{Cu}_{2} \mathrm{AlBO}_{5}$ all sites are partially occupied by $\mathrm{Al}$ and $\mathrm{Cu}$ atoms. M1 and M2 sites are predominately occupied by $\mathrm{Cu}$ atoms with significantly less amount of $\mathrm{Al}(\mathrm{Cu}: \mathrm{Al}=0.88: 0.12$ and 0.86:0.14, respectively); whereas M3 and M4 sites are predominantly occupied by $\mathrm{Al}$ atoms with less amount of $\mathrm{Cu}(\mathrm{Cu}: \mathrm{Al}=0.34: 0.66$ and 0.33:0.67, respectively). The magnetic properties of the investigated homomagnetic copper ludwigites are discussed in comparison with known heterometallic bimagnetic ludwigites.

The magnetic measurements showed that the effective magnetic moment and low-temperature magnetic susceptibility for $\mathrm{Cu}_{2} \mathrm{AlBO}_{5}$ is higher than for 
$\mathrm{Cu}_{2} \mathrm{GaBO}_{5}$. This is probably due to changes in the g-factors of copper ions surrounded by more distorted octahedron from oxygen ions.

The analysis of the phonon contribution to the specific heat was performed, that allowed to separate the magnetic contribution to the specific heat for both compounds. The Debye and Einstein temperatures were obtained from the analysis of the temperature dependence of the specific heat. The joint analysis of low-temperature data on magnetic susceptibility and magnetic contribution to the specific heat showed that antiferromagnetic clusters which formed near defects in $\mathrm{Cu}_{2} \mathrm{AlBO}_{5}$ and $\mathrm{Cu}_{2} \mathrm{GaBO}_{5}$ go into a antiferromagnetic state at $T_{\mathrm{N}} \approx 3 \mathrm{~K}$. The magnetic phase transitions was started in $\mathrm{Cu}_{2} \mathrm{GaBO}_{5}$ at $T=4.0 \mathrm{~K}$, which can be the transition to the antiferromagnetically ordered state in quasi one-dimensional chain formed by copper ion along the $a$-axis. An external magnetic field above $2.5 \mathrm{~T}$ apparently destroys the long-range antiferromagnetic order, but short-range magnetic order is preserved.

\section{Acknowledgments}

The reported study was supported by the Russian Foundation for Basic Research (RFBR), grant No 17-02-00953. T.P.G., R.M.E. acknowledge the financial support from the government assignment for FRC Kazan Scientific Center of RAS. D.S.I. acknowledges funding from the German Research Foundation through the Collaborative Research Center SFB 1143 in Dresden (project C03) and the Würzburg-Dresden Cluster of Excellence on Complexity and Topology in Quantum Matter - ct.qmat (EXC 2147, project-id 39085490). The XRD and EDX measurements have been performed at the X-ray Diffraction Centre and Centre for Microscopy and Microanalysis of the St. Petersburg State University. The magnetometer studies were performed by the subsidy allocated to Kazan Federal University for the state assignment in the sphere of scientific activities.

\section{References}

[1] S. Sofronova, E. Moshkina, I. Nazarenko, Yu. Seryotkin, S. A. Nepijko, V. Ksenofontov, K. Medjanik, A. Veligzhanin, L. Bezmaternykh, Crystal growth, structure, magnetic properties and theoretical exchange interaction calculations of $\mathrm{Cu}_{2} \mathrm{MnBO}_{5}$, J. Magn. Magn. Mater. 420 (2016) 309316.

[2] E. Moshkina, C. Ritter, E. Eremin, S. Sofronova, A. Kartashev, A. Dubrovskiy, L. Bezmaternykh, Magnetic structure of $\mathrm{Cu}_{2} \mathrm{MnBO}_{5}$ ludwigite: thermodynamic, magnetic properties and neutron diffraction study, J. Phys. Condens. Matter. 29 (2017) 245801.

[3] E. M. Moshkina, M. S. Platunov, Yu. V. Seryotkin, A. F. Bovina, E. V. Eremin, S. N. Sofronova, L. N. Bezmaternykh, Transformation of structure and magnetic properties of $\mathrm{Cu}_{2} \mathrm{MnBO}_{5}$ under partial $\mathrm{Mn}^{3+} \rightarrow$ $\mathrm{Fe}^{3+}$ substitution, J. Magn. Magn. Mater. 464 (2018) 1-10. 
[4] L. N. Bezmaternykh, E. M. Kolesnikova, E. V. Eremin, S. N. Sofronova, N. V. Volkov, M. S. Molokeev, Magnetization pole reversal of ferrimagnetic ludwigites $\mathrm{Mn}_{3-x} \mathrm{Ni}_{x} \mathrm{BO}_{5}$, J. Magn. Magn. Mater. 364 (2014) 55-59.

[5] M. A. Continentino, J. C. Fernandes, R. B. Guimarães, H. A. Borges, A. Sulpice, J.-L. Tholence, J. L. Siqueira, J. B. M. da Cunha, C. A. dos Santos, Magnetic interactions in the monoclinic ludwigite $\mathrm{Cu}_{2} \mathrm{FeO}_{2} \mathrm{BO}_{3}$, Eur. Phys. J. B 9 (1999) 613-618.

[6] I. I. Nazarenko, S. N. Sofronova, E. M. Moshkina, Magnetic ordering dependence on iron ions distribution in $\mathrm{Cu}_{2} \mathrm{FeBO}_{5}$ ludwigite, J. Exp. Theor. Phys. 126 (2018) 674-682.

[7] J. C. Fernandes, R. B. Guimarães, M. A. Continentino, H. A. Borges, A. Sulpice, J.-L. Tholence, J. L. Siqueira, L. I. Zawislak, J. B. M. da Cunha, C. A. dos Santos, Magnetic interactions in the ludwigite $\mathrm{Ni}_{2} \mathrm{FeO}_{2} \mathrm{BO}_{3}$, Phys. Rev. B 58 (1998) 287-292.

[8] D. C. Freitas, M. A. Continentino, R. B. Guimarães, J. C. Fernandes, E. P. Oliveira, R. E. Santelli, J. Ellena, G. G. Eslava, L. Ghivelder, Partial magnetic ordering and crystal structure of the ludwigites $\mathrm{Co}_{2} \mathrm{FeO}_{2} \mathrm{BO}_{3}$ and $\mathrm{Ni}_{2} \mathrm{FeO}_{2} \mathrm{BO}_{3}$, Phys. Rev. B 79 (2009) 134437 1-8.

[9] G. A. Petrakovskii, L. N. Bezmaternykh, D. A. Velikanov, A. M. Vorotynov, O. A. Bayukov, M. Schneider, Magnetic properties of single crystals of ludwigites $\mathrm{Cu}_{2} \mathrm{MBO}_{5}\left(M=\mathrm{Fe}^{3+}, \mathrm{Ga}^{3+}\right)$, Phys. Solid State 51 (2009) 20772083.

[10] G. A. Petrakovskii, L. N. Bezmaternykh, D. A. Velikanov, M. S. Malokeev, O. A. Bayukov, A. M. Vorotynov, R. Szymchak, Magnetic properties of the $\mathrm{CuCoAlBO}_{5}$ single crystal, Phys. Solid State 51 (2009) 2486-2491.

[11] N. B. Ivanova, N. V. Kazak, Yu. V. Knyazev, D. A. Velikanov, A. D. Vasiliev, L. N. Bezmaternykh, M. S. Platunov, Structure and magnetism of coppersubstituted cobalt ludwigite $\mathrm{Co}_{3} \mathrm{O}_{2} \mathrm{BO}_{3}$, Low Temperature Physics 39 (2013) 709-713.

[12] L. Bezmaternykh, E. Moshkina, E. Eremin, M. Molokeev, N. Volkov, Yu. Seryotkin, Spin-lattice coupling and peculiarities of magnetic behavior of ferrimagnetic ludwigites $\mathrm{Mn}_{0.5}^{2+} \mathrm{M}_{1.5}^{2+} \mathrm{Mn}^{3+} \mathrm{BO}_{5}(M=\mathrm{Cu}, \mathrm{Ni})$, Solid State Phenom. 233-234 (2015) 133-136.

[13] M. Balanda, AC susceptibility studies of phase transitions and magnetic relaxation: conventional, molecular and low-dimensional magnets, Acta Physica Polonica A 124 (2013) 964-976. 
[14] J. A. Hriljac, R. D. Brown, A. K. Cheetham, The synthesis and crystal structures of the related series of aluminoborates: $\mathrm{Co}_{2.1} \mathrm{Al}_{0.9} \mathrm{BO}_{5}, \mathrm{Ni}_{2} \mathrm{AlBO}_{5}$, and $\mathrm{Cu}_{2} \mathrm{AlBO}_{5}$, J. Sol. Stat. Chem. 84 (1990) 289-298.

[15] G. M. Sheldrick, SADABS. Univ. Göttingen, Germany (2007).

[16] CrysAlisPro, Rigaku Oxford Diffraction, Version 1.171.39.35a, 2017.

[17] G. M. Sheldrick, Crystal structure refinement with SHELXL, Acta Cryst. C C71 (2015) 3-8.

[18] O. V. Dolomanov, L. J. Bourhis, R. J. Gildea, J. A. K. Howard, H. Puschmann, OLEX2: A complete structure solution, refinement and analysis program, J. Appl. Cryst. 42 (2009) 339-341.

[19] A. Linden, Best practice and pitfalls in absolute structure determination, Tetrahedron: Asymmetry 28 (2017) 1314-1320.

[20] R. M. Eremina, E. M. Moshkina, T. P. Gavrilova, I. F. Gilmutdinov, S. N. Sofronova, A. G. Kiiamov, Investigation of the Magnetic Properties of Ludwigites, Bulletin of the Russian Academy of Sciences: Physics 83 (2019) 912-914.

[21] H. Neuendorf, W. Gunßer, Transition from quasi-one-dimensional to spinglass behaviour in insulating $\mathrm{FeMg}_{2} \mathrm{BO}_{5}$, J. Magn. Magn. Mater. 173 (1997) 117-125.

[22] J. Schaefer, K. Bluhm, Zur Kristallstruktur von $\mathrm{Cu}_{2} \mathrm{M}\left(\mathrm{BO}_{3}\right) \mathrm{O}_{2},\left(\mathrm{M}=\mathrm{Fe}^{3+}\right.$, $\mathrm{Ga}^{3+}$ ), Z. anorg. allg. Chem. 621 (1995) 571-575.

[23] A. L. Geiler, V. G. Harris, C. Vittoria, N. X. Sun, quantitative model for the nonlinear response of fluxgate magnetometers, J. Appl. Phys. 99 (2006) 08B316 1-4.

[24] J. Deisenhofer, R. M. Eremina, A. Pimenov, T. Gavrilova, H. Berger, M. Johnsson, P. Lemmens, H.-A. Krug von Nidda, A. Loidl, K.-S. Lee, M.$\mathrm{H}$. Whangbo, Structural and magnetic dimers in the spin-gapped system $\mathrm{CuTe}_{2} \mathrm{O}_{5}$, Phys. Rev. B 74 (2006) 174421 1-8.

[25] A. Golubev, R. E. Dinnebier, A. Schulz, R. K. Kremer, H. Langbein, A. Senyshyn, J. M. Law, T. C. Hansen, H.-J. Koo, M.-H. Whangbo, Structural and Magnetic Properties of the Trirutile-type 1D-Heisenberg AntiFerromagnet $\mathrm{CuTa}_{2} \mathrm{O}_{6}$, Inorg. Chem. 56 (2017) 6318-6329.

[26] J. Xu, A. Assoud, N. Soheilnia, S. Derakhshan, H. L. Cuthbert, J. E. Greedan, M. H. Whangbo, H. Kleinke, Synthesis, Structure, and Magnetic Properties of the Layered Copper(II) Oxide $\mathrm{Na}_{2} \mathrm{Cu}_{2} \mathrm{TeO}_{6}$, Inorg. Chem. 44 (2005) 5042-5046. 
[27] M. Schmitt, O. Janson, S. Golbs, M. Schmidt, W. Schnelle, J. Richter, H. Rosner, Microscopic magnetic modeling for the $S=1 / 2$ alternatingchain compounds $\mathrm{Na}_{3} \mathrm{Cu}_{2} \mathrm{SbO}_{6}$ and $\mathrm{Na}_{2} \mathrm{Cu}_{2} \mathrm{TeO}_{6}$, Phys. Rev. B 89 (2014) $1744031-10$.

[28] D. C. Johnston, R. K. Kremer, M. Troyer, X. Wang, A. Klumper, S. L. Bud'ko, A. F. Panchula, P. C. Canfield, Thermodynamics of spin $S=1 / 2$ antiferromagnetic uniform and alternating-exchange Heisenberg chains, Phys. Rev. B 61 (2000) 9558-9606.

[29] J. C. Fernandes, R. B. Guimarães, M. Mir, M. A. Continentino, H. A. Borges, G. Cernicchiaro, M. B. Fontes, E. M. Baggio-Saitovitch, Magnetic behaviour of ludwigites, Physica B 281-282 (2000) 694-695.

[30] D. C. Freitas, M. A. Continentino, R. B. Guimarães, J. C. Fernandes, J. Ellena, L. Ghivelder, Structure and magnetism of homometallic ludwigites: $\mathrm{Co}_{3} \mathrm{O}_{2} \mathrm{BO}_{3}$ versus $\mathrm{Fe}_{3} \mathrm{O}_{2} \mathrm{BO}_{3}$, Phys. Rev. B 77 (2008) 184422 1-8.

[31] R. B. Guimarães, M. Mir, J. C. Fernandes, M. A. Continentino, H. A. Borges, G. Cernicchiaro, M. B. Fontes, D. R. S. Candela, E. BaggioSaitovitch, Cation-mediated interaction and weak ferromagnetism in $\mathrm{Fe}_{3} \mathrm{O}_{2} \mathrm{BO}_{3}$, Phys. Rev. B 60 (1999) 6617-6622.

[32] R. M. Eremina, T. P. Gavrilova, A. Günther, Z. Wang, R. Lortz, M. Johnsson, H. Berger, H. A. Krug von Nidda, J. Deisenhofer, A. Loidl, Magnetization and specific heat of the dimer system $\mathrm{CuTe}_{2} \mathrm{O}_{5}$, Eur. Phys. J. B 84 (2011) 391-395.

[33] Y. V. Lysogorskiy, R. M. Eremina, T. P. Gavrilova, O. V. Nedopekin, D. A. Tayurskii, Vibrational and magnetic properties of crystalline $\mathrm{CuTe}_{2} \mathrm{O}_{5}$, JETP Lett. 100 (2015) 652-656.

[34] A. Bloise, E. Barrese, C. Apollaro, D. Miriello, Synthesis of ludwigite along the $\mathrm{Mg}_{2} \mathrm{FeBO}_{5} \mathrm{Mg}_{2} \mathrm{AlBO}_{5}$ join, Neues Jahrbuch für Mineralogie - Abhandlungen: J. Mineral. Geochem. 187 (2010) 217-223.

[35] E. S. R. Gopal, Specific heats at low temperatures (Heywood, London, 1966).

[36] K. Binder, A. P. Young. Spin glasses: Experimental facts, theoretical concepts, and open questions, Rev. Mod. Phys. 58 (1986) 801-976.

[37] V. Grinenko, S.-L. Drechsler, M. Abdel-Hafiez, S. Aswartham, A. U. B. Wolter, S. Wurmehl, C. Hess, K. Nenkov, G. Fuchs, D. V. Efremov, B. Holzapfel, J. van den Brink, B. Büchner, Disordered magnetism in superconducting $\mathrm{KFe}_{2} \mathrm{As}_{2}$ single crystals, Phys. Status Solidi B 250 (2013) 593-598. 
[38] P. Skornia, J. Goraus, M. Fijałkowski, A. Ślebarski, Electronic structure and magnetic properties of the magnetically ordered intermediate valent $\mathrm{Ce}_{5} \mathrm{RuGe}_{2}$, J. Alloys Compd. 767 (2018) 512-521.

[39] S. V. Demishev, A. V. Semeno, N. E. Sluchanko, N. A. Samarin, I. E. Tarasenko, ESR probing of quantum critical phenomena in doped $S=1 / 2 \mathrm{AF}$ quantum spin chain, Applied Magnetic Resonance 35 (2009) $327-335$.

[40] V. N. Glazkov, A. I. Smirnov, O. A. Petrenko, D. McK. Paul, A. G. Vetkin, R. M. Eremina, Electron spin resonance in the doped spin-Peierls compound $\mathrm{Cu}_{1-x} \mathrm{Ni}_{x} \mathrm{GeO}_{3}$, J. Phys.: Condens. Matter 10 (1998) 7879-7896. 